\title{
O SONHO DE BALZAC: COMÉDIA HUMANA OU BÍBLIA MUNDANA?
}

\author{
BALZAC'S DREAM: HUMAN COMEDY OR MUNDANE BIBLE?
}

Lucius de Mello*

Resumo: Este artigo analisa o diálogo intertextual entre a Bíblia e uma pequena galeria dos romances e histórias que constituem A Comédia Humana de Honoré de Balzac. Com base em ensaios recentes de críticos franceses, apontamos que Balzac teria usado a estrutura da narrativa bíblica e algumas de suas histórias e personagens como referência, modelo e inspiração para elaborar o seu grande projeto literário. Sob a pluma e a ironia balzaquianas, Paris é vista como uma terra prometida ao contrário, "a sucursal do inferno", e A Comédia Humana pode ser lida como uma Bíblia Mundana.

Palavras-chave: Balzac. Bíblia. Comédia Humana. Demi-monde. Cortesã.

Abstract: This article analyzes the intertextual dialogue between the Bible and a small gallery of novels and stories that constitute Honoré de Balzac's The Human Comedy. Based on recent essays by French critics we point out that Balzac would have used the structure of the biblical narrative and some of the stories and characters as a reference, model and inspiration to develop his great literary Project. Under Balzac's ironic plume, Paris is seen as a promised land in reverse, "a branch of hell", and The Human Comedy may be read as a Mundane Bible.

Keywords: Balzac. Bible. Human Comedy. Underworld. Courtesan.

A cortesã arrependida há de ser sempre uma mistificação para a Igreja; se alguma aparecesse, havia de voltar a ser cortesã no paraíso.

(Honoré de Balzac)

Bíblia e Comédia. Textos que, praticamente, nos remetem ao nascimento das línguas. De origem grega, a palavra Bíblia vem de Byblos, que no vocabulário grego quer dizer papiro, planta abundante às margens do rio Nilo usada pelas civilizações antigas para escrever; o plural de Byblos é bíblia, vocábulo que significa, literalmente, livros, e foi a partir de uma tradução realizada na Alexandria helenística dos séculos III e II a.C. (denominada como tradução grega dos LXX ou Septuaginta), que o corpus bíblico passou a ser chamado bíblia, ou seja, os livros. Antes disso, segundo os exegetas, não tinha propriamente um nome.

Já a origem da palavra Comédia é atribuída às festas em homenagem a Dioniso ou Baco; celebrações carnavalescas representadas por orgias e bacanais e, como define Aristóteles no capítulo V da sua Poética:

A Comédia é a mimese dos homens inferiores, não, todavia, de toda espécie de vício: o cômico é apenas uma parte do feio. ${ }^{1}$

\footnotetext{
* Doutorando em Letras pela Université Sorbonne - Paris (Programa CAPES/PRINT) e Universidade de São Paulo. E-mail: <luciusdemello@uol.com.br>e/ou <luciusdemello@usp.br>.

${ }^{1}$ Aristóteles usa cinco termos diferentes para se referir à comédia: phaulóterõn, kakía, aiskhrón, hamártēma e aískhos, os quais o tradutor da obra, Paulo Pinheiro, verteu, respectivamente, como homens inferiores, vício, feio, erro e vergonha.
} 
Poder-se-ia dizer que o cômico é um determinado erro e uma vergonha que não causam dor e destruição; como bem exemplifica a máscara cômica: ela é feia e disforme sem expressar dor. (ARISTÓTELES, 2019, p.67)

Em Balzac, o conceito de Comédia é metáfora da sociedade francesa, da civilização ocidental do século XIX e de uma das escrituras mais longevas da humanidade: a narrativa bíblica. Num gesto ousado e subversivo, o autor francês veste a Bíblia com as cores profanas e irreverentes da comédia, a sua desconcertante Comédia Humana. Balzac ironiza, parodia, usa modelos religiosos em seus romances. É o que afirma Vincent Bierce em seu livro Le Sentiment Religieux dans La Comédie Humaine: Foi, ironie et ironisation, publicado no ano passado, e que resulta de sua tese defendida com o mesmo título na École Normale Supérieure de Lyon. Segundo o pesquisador,

Na Comédia Humana, a ironização do sentimento religioso passa por efeitos que são desenvolvidos em diferentes escalas: à escala de um romance inteiro, envolvendo o significado geral de uma obra, mas, igualmente, a uma escala bem menor, à escala de uma frase ou mesmo simplesmente de uma palavra. O léxico da religião aparece como um vetor de escolha para exprimir toda uma visão crítica do mundo e desenvolver a representação de uma sociedade pósrevolucionária que trabalha e tenta viver sem Deus. ${ }^{2}$ (BIERCE, 2019, p. 610, tradução nossa ${ }^{3}$ )

De acordo com Bierce, nós assistimos na Comédia Humana a “(...) uma forma de carnavalização do vocabulário religioso, isto é, assistimos a processos repetidos de uma desvalorização cômica de um léxico inteiro cujas múltiplas realizações aparecem como sintomas de uma crise religiosa e social"4 (BIERCE, 2019, p.616). E isso ocorre apesar de toda admiração que Balzac sentia pela Igreja e pela aristocracia: "a sua sátira nunca é tão cáustica e a sua ironia nunca é tão amarga como quando ele põe em cena aqueles homens e mulheres com os quais mais profundamente simpatiza: os aristocratas" (LUCKÁCS, 1965, p.36).

Mas como Balzac teria chegado ao título A Comédia Humana, que consegue traduzir a sua completa visão do mundo? A relação imediata com a Divina Comédia de Dante faz todo sentido, afirmam pesquisadores. Na biografia que escreveu sobre Balzac, Stefan Zweig destaca que a ideia teria ganhado força depois de uma conversa entre o escritor e o seu amigo e exsecretário de redação, Bellay, recém-chegado da Itália e que acabara de ler a Divina Comédia no texto original. Segundo Zweig, os dois teriam conversado muito sobre o assunto: "Subitamente surge em Balzac a pergunta: por que não opor à comédia divina a terrena, ao edifício teológico o sociológico?" (ZWEIG, 1953, p.355)

\footnotetext{
${ }^{2}$ Dans La Comédie Humaine, l'ironisation du sentiment religieux à l'oeuvre passe par des effects d'ironisation qui sont développés à différentes échelles: à l'échelle d'un roman entier, engageant alors les sens global d'une oeuvre, mais également à une échelle bien plus petite, à l'échelle d'une phrase ou même simplement d'un mot. Le lexique de la religion apparait alors comme un vector de choix pour exprimer toute une vision critique du monde et développer la répresentation d'une société post-révolucionnaire qui travaille à se passer de Dieu.

${ }^{3}$ Como os referidos livros dos críticos Vicent Bierce, Anne-Marie Baron, Philippe Bertault, Philippe Sellier, Alain Schaffner e Sylvie Parizet não são publicados no Brasil, todas as traduções das citações desses pesquisadores(as) que aparecem neste artigo são de minha autoria.

${ }^{4}(\ldots)$ à une forme de carnavalisation $d u$ vocabulaire religieux, c'est-à-dire à des procédés répétés de dévalorisation comique de tout un lexique dont les réalisations multipliques se donneraient à lire comme autant de symptômes d'une crise religieuse et sociale.
} 
Segundo Anne-Marie Baron, Balzac não só se inspirou na Divina Comédia mas também quis acentuar o grau de parentesco com a obra do poeta italiano. Em 1839, depois que o título de A Comédia Humana foi escolhido, ele ainda escreveu o romance Beatriz, que leva o mesmo nome da heroína de Dante, ou seja, Balzac “(...) fez de Beatriz o símbolo da pureza revivida e coloca em cena muitas figuras explicitamente dantescas"5 (BARON, 2018, p.265). Baron acredita que "Balzac procura escrever como Dante o épico do Homem. [...] o mais importante

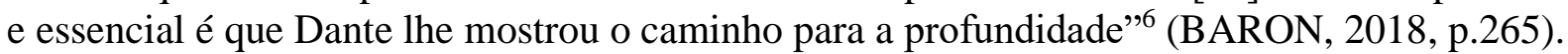

Balzac, ironicamente, chega até a se comparar a Deus em uma das cartas que escreve a madame Hanska para reclamar do trabalho titânico que a sua obra literária lhe causava: "Após quinze anos de trabalho constante não aturo mais esta eterna luta solitária. Criar, sempre criar. O próprio Deus empregou somente seis dias na criação" (BALZAC apud ZWEIG, 1953, t. XIX, p.347).

Essa postura de Balzac de se denominar inventor de um mundo - neste caso, de uma obra-mundo ${ }^{7}$ - e de aproximar a Bíblia à Comédia, também foi sinalizada num levantamento feito por Pierre Citron e Anne-Marie Meininger. Referindo-se a esse relatório ${ }^{8}$ no seu ensaio Balzac, leitor da Bíblia, Jean-Hérve Donnard destaca que "a Bíblia é a obra mais citada na Comédia Humana" (DONNARD, 1988, p.7). As ramificações dos relatos bíblicos que despontam e se espalham pela prosa balzaquiana ilustram um surpreendente encontro intertextual entre dois trabalhos de ficção: A Comédia Humana e a Bíblia. Essa última também pode ser considerada uma narrativa fictícia, especialmente quando nos amparamos nas palavras de Robert Alter: "Especificando detalhes narrativos e inventados diálogos que individualizam os personagens e dão foco às suas relações, os escritores da Bíblia conferem aos acontecimentos que relatam um tempo e um lugar ficcionais" (ALTER, 2007, p.72). Nesse sentido Northrop Frye, muito antes de Alter, já esclarecia: "Parece claro que a Bíblia pertence a uma área da linguagem onde a metáfora é funcional, e onde devemos desistir da precisão pela flexibilidade" (FRYE, 2006, p.83). Para Frye, “(...) muitos pontos relevantes da teoria crítica de hoje tiveram origem no estudo hermenêutico da Bíblia” (Ibid., p.18).

Considerada por muitos pensadores como texto fundador da literatura, com raízes profundas na História, "coleção de livros mais lida e traduzida em todo mundo" (SELLIER, 1990, p.11), a narrativa bíblica é fonte que alimenta e alimentou a imaginação dos nossos maiores escritores. "A fertilidade do texto bíblico é realmente impressionante. Ela excede largamente as épocas e os temas abordados ao revelar riquezas jamais imaginadas" (PARIZET, 2016, p.5), escreve Sylvie Parizet na introdução do grande dicionário que organizou (La Bible dans les littératures du monde) com a participação de 400 pesquisadores. Um ambicioso trabalho que, segundo Parizet, foi realizado "para melhor entender as perguntas vitais que a Bíblia ecoa na criação literária” (PARIZET, 2016, p.11). Perguntas que levaram Harold Bloom a considerar a narrativa bíblica como dona de "esplendor estético, força intelectual e sapiência" (BLOOM, 2009, p.13). Segundo o crítico norte-americano, há livros na Bíblia com a força de Shakespeare e de Cervantes: "Hamlet está no centro do cosmos literário, tanto oriental quanto ocidental. Seus únicos rivais são cômicos - Dom Quixote - ou beiram a divindade como o Jesus

\footnotetext{
${ }^{5}$ (...) fait de Béatrix le symbole de la pureté retrouvée et met en scène de nombreuses figures explicitement dantesques.

${ }^{6}$ Balzac cherche à écrire, comme Dante, l'épopée de l'homme. [...] l'essentiel est surtout que Dante lui a montré la voie de la profondeur.

${ }^{7}$ Segundo Stefan Zweig, um dos biógrafos de Balzac, o plano original do autor era de que A Comédia Humana fosse composta por 144 obras com três a quatro mil personagens. Balzac, porém, morreu antes de completar o seu grandioso projeto. Ainda conforme Zweig, A Comédia Humana em seu estado incompleto - versão que temos hoje - é formada por 94 romances, contos e novelas e 2 mil personagens. (ZWEIG, 1953, p.357)

${ }^{8}$ Donnard indica que se baseou no índice de obras citadas, organizado por Pierre Citron e Anne-Marie Meininger, publicado na Plêiade, v. XII, p.1847.
} 
incrivelmente enigmático do Evangelho de Marcos, que não tem certeza de quem é e insiste em perguntar a seus discípulos estúpidos: Mas quem ou o que dizem que sou? (BLOOM, 2013, p.58).

Os ecos da narrativa bíblica na Comédia Humana chamam a atenção porque vão muito além de uma simples citação ou inspiração, pontua Baron. Segundo a autora, por “(...) absorção, transformação, dilatação, relativização, paródia, a Bíblia torna-se assim matéria balzaquiana e o romance de Balzac palimpsesto ${ }^{9}$ bíblico" (BARON apud PARIZET, 2016, p.354).

Baron e muitos outros especialistas não têm dúvida de que Balzac foi um grande leitor da Bíblia, especialmente da edição traduzida da Vulgata (versão latina) para o francês por Lemaitre de Sacy no século XVII.

Com a Bíblia à mão ou na mente, como o autor sugere no prefácio que escreveu para A Comédia Humana, a riqueza, a variedade e a profundidade das Escrituras o estimularam a beber nessa fonte, a experimentar o sublime religioso com o qual ele simpatizava desde a infância. (BARON, 2018, p.347).

As conexões com a Bíblia começam pela estrutura da Comédia Humana que também é composta por uma pequena biblioteca e personagens que interagem e conversam entre si num complexo sistema narrativo. A Bíblia, somados o Velho e o Novo Testamentos, tem 66 livros; A Comédia Humana 94. Assim como a Bíblia separa os seus temas por categorias sóciopolíticas, juízes, grandes e pequenos profetas, reis etc., a Comédia Humana também agrupa suas histórias por recortes político-sociais em três áreas distintas: Estudos Analíticos, Estudos Filosóficos e Estudos de Costumes; este último está organizado em Cenas da Vida Privada, Cenas da Vida Provinciana, Cenas da Vida Rural, Cenas da Vida Política, Cenas da Vida Militar e Cenas da Vida Parisiense.

Aliás, segundo Baron, a épica Paris, sob a pluma de Balzac, "é uma cidade amaldiçoada por excelência, uma nova Babel""10 (BARON, 2018, p.48). Citando frases presentes nas obras de Balzac, a pesquisadora conclui: "herdeira de Ninive, da Babilônia e da Roma Imperial onde parece não ter fim a convivência entre o luxo e a miséria, o vício e a honestidade, o desejo reprimido e a implacável tentação; moderna Sodoma entregue ao ouro e ao prazer" 11 (Ibid.).

O pesquisador Philippe Berthier também fez essa aproximação entre Paris e a cidade maldita: “(...) no quesito luxúria, poderia muito bem estar 'Du côté de Sodome”" (2010, p.223). Até o campo viveu dias de Sodoma em algumas obras de Balzac. É o caso da ville de Issoudun. Segundo Zweig, "O problema da perversão e da escravidão sexual não foi tratado por ninguém com tanto arrojo como por Balzac na figura do malvado doutor Rouget, que, septuagenário, educa a Rabouilleuse, de treze anos, para sua amante e do seu filho, que depois se torna vítima desta" (ZWEIG, 1953, p.353). O autor refere-se à história de Flora Brazier - "essa ninfa" (Ibid., p.107) -, a angélica criança, catadora de caranguejos, protagonista do romance La Rabouilleuse (1843), que teve seu título alterado nas edições portuguesa e brasileira para Um conchego de solteirão.

Esse romance é mais um exemplo de como as cenas bíblicas e a ironização do sentimento religioso florescem na criação balzaquiana: "(...) a mais bela cabeleira loura que uma filha de Eva tenha podido desejar" (Ibid., p.107). Num casarão todo decorado com quadros sacros como

\footnotetext{
${ }^{9}$ Palimpsesto é uma palavra de origem grega que significa papiro ou pergaminho, cujo texto primitivo foi raspado para dar lugar a outro.

${ }^{10}$ (...) ville maudite par excellence, nouvelle Babel.

11 (...) héritière des Ninive, des Babylone et de la Rome Impériale par l'incessant concubinage du Luxe e de la Misère, du Vice et de l'Honnêteté, du Désir réprimé et de la Tentation renaissante, moderne Sodome livrée à l'or et au plaisir.
} 
uma Santa Família, de Albani, uma Cabeça de Cristo, de Giovanni Bellini, uma Virgem, de Leonardo da Vinci, e uma Via Sacra, de Tizano, entre outros, o diabólico e libertino médico abusava sexualmente da menina: "A pequena Batedora estava tão contente comparando sua situação na casa do doutor com a vida que teria levado com seu tio Brazier, que certamente se curvou às exigências do patrão, como teria feito uma escrava no Oriente" (BALZAC, 1958, v. VI, p.112-113).

Nesses quase dois séculos que se passaram após a morte de Balzac, A Comédia Humana foi estudada quase à exaustão. Segundo Paulo Rónai, "os trabalhos que lhe dizem respeito formam uma biblioteca inteira" (RÓNAI, 2012, p.14). Mesmo assim, poucos pesquisadores se interessaram por esse tema. Em L'Année Balzacienne, a mais prestigiada revista de estudos balzaquianos, editada anualmente e de forma ininterrupta há 60 anos, foram publicados apenas dois ensaios que analisam o diálogo entre Balzac e a Bíblia, nove sobre Balzac e a Religião, e quatro sobre Balzac e Deus, entre os anos de 1960 e 1999. Nesse mesmo período, 367 especialistas de todo mundo publicaram na L'Année Balzacienne sobre 287 temas diferentes. Ao contrário da Bíblia, os assuntos que mais despertaram o interesse dos pesquisadores foram, em terceiro lugar, o Realismo (18), em segundo, a Mulher (22), e, em primeiro lugar, A Revolução (30).

Do ano 2000 até 2019 foram publicados outros 21 ensaios sobre a religião, a Bíblia e o misticismo em Balzac. Em 2013 a revista dedicou uma edição inteira sobre esse tema. Até o momento da finalização deste ensaio a edição de 2020 ainda não tinha sido publicada.

A primeira grande referência sobre esse assunto ocorreu no estudo realizado por Phlippe Bertault, em 1942. A partir da obra, da vida pessoal de Balzac e da sua relação, principalmente, com o Catolicismo e com o Cristianismo de uma forma geral, Bertault escreveu uma tese de 561 páginas defendida na Sorbonne e publicada pouco depois com o título Balzac et la Religion. Na conclusão da pesquisa, Bertault destaca o dualismo religioso de Balzac e o viés subversivo da pluma balzaquiana quando escreve sobre a Bíblia:

A religião de Balzac era verdadeiramente dele, ele a havia composto para seu uso. Ela lhe dava completa paz. A Igreja à qual pertenceu não era de nenhuma ordem ou congregação; dela foi ele o fundador, dela foi ele o único seguidor. ${ }^{12}$ (BERTAULT, 2002, p.495)

Bertault não chegou a essa conclusão sozinho. Ao longo de A Comédia Humana, Balzac deixa muitos vestígios - bem claros, por sinal - do seu interesse pela Bíblia e da sua obsessão em fazer uma leitura bem particular e transgressora de algumas de suas passagens e personagens.

No romance La Peau de Chagrin, primeiro grande sucesso de Honoré de Balzac e que, portanto, representa o início oficial do seu projeto literário, temos um exemplo dessa ousada operação do escritor. Nessa obra, segundo o pesquisador Alain Schaffner, estaria a "pedra angular", a chave principal para a compreensão da Comédia Humana. Ele esclarece:

Seu status intermediário, cronologicamente (entre a veia fantástica e a veia realista) e, logicamente, (entre os Estudos filosóficos e os Estudos de costumes), geralmente levavam os críticos a marginalizar esse romance e considerá-lo uma exceção na criação balzaquiana. Na década de 1940, Maurice Bardèche sublinhou o caráter resolutamente alegórico da narrativa e extraiu dela um argumento, não para minimizar sua importância, mas para

\footnotetext{
${ }^{12}$ La religion de Balzac était vraiment sienne, il l'avait composée pour son usage. Elle lui donnait tout apaisement. L'Eglise à laquelle il appartint ne relevait d'aucune obédience; il en était le fondateur, il en fut le seul adepte.
} 
demonstrar a primazia da intenção filosófica em Balzac. ${ }^{13}$ (SCHAFFNER, 1996, p.116, grifos nossos)

Seguindo por esse caminho, destacamos um trecho do romance La Peau de Chagrin, que, em português, ficou conhecido como A Pele de Onagro. Trata-se do momento em que o narrador, logo no começo da história, descreve a visita que o protagonista Raphael de Valentin faz a um antiquário no centro de Paris e o seu encantamento diante das raridades:

Uma pintura abria os céus, e ele via a Virgem Maria mergulhada numa nuvem de ouro, no seio dos anjos, eclipsando a glória do sol, escutando as queixas dos infelizes aos quais essa Eva regenerada sorria com doçura. (BALZAC, 2008, p.43)

Reparemos na expressão Eva regenerada. Ela nos sinaliza a imagem que o narrador balzaquiano faz de Maria, ou seja, que ele vê a mãe de Jesus - figura feminina fundamental do Cristianismo - como uma nova Eva. Influenciado por esse olhar, o leitor atento fará a conexão entre as duas personagens do Velho e do Novo Testamentos. No fragmento que acabamos de ver, a Eva regenerada (Maria) reina no Paraíso celeste sob o sol, em meio às nuvens douradas, anjos e docilidade ao passo que a sua versão primeva (Eva) - figura central do Judaísmo - foi subversiva e expulsa do Paraíso.

A ideia balzaquiana da volta de Eva à nova Bíblia Cristã é proposta pelo narrador de $L a$ Peau de Chagrin justamente no momento em que Balzac começa a pensar em colocar em ação a técnica do reaparecimento das suas personagens. A trama protagonizada por Raphael de Valentin e Fedora introduz as primeiras criaturas nascidas sob a pluma de Balzac que se eternizaram em outros romances, como Eugène de Rastignac e o médico Horace Bianchon que reaparecerão, três anos mais tarde, em Le Père Goriot. Segundo o crítico Paulo Rónai,

Haverá livros em que o número das personagens reaparecentes é superior a cem; em Esplendores e misérias das cortesãs vai além de 150. [...] O que há de realmente curioso na aplicação desse recurso é que Balzac nunca se engana. A mesma pessoa sempre reaparece com os olhos da mesma cor, a mesma constituição física, o mesmo temperamento - e as modificações de fisionomia ou de índole que apresenta sempre se explicam pelo tempo decorrido ou pelos acontecimentos dos romances. (RÓNAI, 2012, p.21-22)

É certo que a Eva pecadora e a Eva Regenerada (Maria) são personagens de épocas e histórias bem distintas, têm nomes e teriam traços físicos distintos também. No entanto, como figuras balzaquianas, também pertencem a livros diferentes que compõem uma única obra. $\mathrm{O}$ narrador de Balzac as colocou frente a frente no espelho para sinalizar uma possível leitura da arquitetura da narrativa bíblica, ou seja, a de que o Novo Testamento seria o Velho Testamento reinventado, adaptado agora a uma nova fase da história da Humanidade, no caso, à Era Cristã. "Jesus e Maria não seriam através de um estudo figurativo o novo Adão e Eva?" (BARON, 2018, p.347), pergunta Anne-Marie Baron, em seu livro Balzac e a Bíblia.

\footnotetext{
${ }^{13}$ Son statut intermédiaire, chronologiquement (entre la veine fantastique et la veine réaliste) et logiquement (entre les Études philosophiques et les Études de mœurs), conduisit généralement les interprètes à le marginaliser, ou à le considérer comme une exception dans la création balzacienne. Maurice Bardèche, renversant la perspective dans les années 1940, souligna le caractère résolument allégorique du roman et en tira argument, non pour en minimiser l'importance, mais pour démontrer la primauté de l'intention philosophique chez Balzac.
} 
A Eva regenerada citada pelo narrador de La Peau de Chagrin é um indício de que o autor refletiu acerca do possível renascimento e reinvenção da narrativa bíblica, seja para marcar o começo do Cristianismo em Belém na província romana da Judeia durante o reinado de Herodes entre 6 e 4 a.C. - prováveis anos do nascimento de Jesus segundo os evangelhos de Lucas e Mateus; seja também para cristalizar a reinterpretação balzaquiana da narrativa bíblica, agora transplantada do Oriente para o Ocidente.

A fertilização do Novo pelo Velho Testamento (Bíblia hebraica) chama a atenção também de críticos do século XXI: "O rei Davi inicia o salmo 22 lamentando-se - 'Senhor, por que me desamparaste?'; trata-se do clamor do seu descendente, Jesus Nazareno, na cruz”.(BLOOM, 2009, p.15-16).

La Peau de Chagrin - livro gênesis do cânone balzaquiano -, considerado por Stefan Zweig "o seu primeiro verdadeiro romance" (1953, p.108), o anfitrião dos Estudos Filosóficos, é escrito e publicado entre 1830 e 1831, período de escuridão, explosões sociais e violência; um momento politicamente sombrio da sociedade parisiense que ainda enfrentava as consequências da Revolução que restituiu o domínio à burguesia após a Restauração. Mas, ao iniciar a criação do seu mundo, nessa sociedade subversiva, mais infernal que religiosa e paradisíaca, Balzac não transforma trevas em luz, muito pelo contrário. $\mathrm{O}$ autor valoriza as sombras e a obscuridade do coração humano, alça o Diabo ao papel de protagonista e, ao contrário da narrativa do Velho Testamento, faz a figura feminina roubar a cena da masculina e desempenhar o transgressor papel de cúmplice e fundador da sua Comédia Humana: "(...) observei as mulheres, estudei-as, fiquei as conhecendo e aprendi a amá-las eternamente", (BALZAC apud ZWEIG, 1953, p. 215), escreve Balzac à Madame Hanska.

As Evas de Balzac tiveram um papel crucial na transformação do "escritor das incompreendidas" (ZWEIG, 1953, p.219), num dos maiores ficcionistas do século XIX: "Jamais um escritor compreendeu tão profundamente a alma feminina. Que sentimento para com as mulheres abandonadas, para com as amarguradas, para com as repudiadas, que tocante indulgência para com todos os seus erros e fraquezas" (ZWEIG, 1953, p.202).

Para Balzac, o conceito de mulher vai bem além do feminino e, muitas vezes, se confunde as formas de expressão da Arte e da Literatura: "Era mais que uma mulher, era um romance" (BALZAC, 1959, v. XV, p.101). No romance $O$ Lírio do Vale, impressionada com o conhecimento que o protagonista Fèlix de Vandenesse tem da alma feminina, a Sra. de Mortsauf pergunta ao jovem apaixonado ${ }^{14}$ : "Já foi mulher alguma vez?" (BALZAC, 1959, v. XIV, p.279). Na vida real, Balzac escreveu à sua, então, futura amante, Madame de Berny, que o inspirou a criar a Sra. de Mortsauf, cerca de 22 anos mais velha do que ele, para convencê-la a ter coragem de viver um romance com um homem tão mais moço:

Deus, se eu fosse mulher, se tivesse 45 anos e ainda fosse digna de ser amada, oh! procederia de modo diferente do seu! Que problema é ser uma mulher que se acha no começo do seu outono e se recusa a colher a maçã que levou Adão e Eva à desgraça! (BALZAC apud ZWEIG, 1953, p.70)

Aliás, seja nessa ou em outras obras de Balzac, a ironia, como esclarece Bierce, é uma chave importante para a compreensão do sentimento místico em A Comédia Humana. Segundo o pesquisador, "a representação do pensamento religioso balzaquiano se funde sob o que nós chamamos de ironização"15 (2019, p.459). A ironização balzaquiana recusa qualquer tentativa

\footnotetext{
${ }^{14}$ Personagem em que, segundo Rónai, "Balzac pôs de certo muito de si mesmo" (RÓNAI, 1959, v. XIV, p.228).

15 (...) la représentation du sentiment religieux se fonde sur ce que nous appelons l'ironisation.
} 
de congelar o significado e "permite, assim, manter os opostos unidos, o religioso e o materialismo, a dúvida e a fé e dá à luz uma unidade radicalmente polifônica que institui a dúvida e a reversibilidade como princípios poéticos. ${ }^{16}$ (Ibid., p.809)

Diante da desafiadora impenetrabilidade de A Comédia Humana, Bierce vislumbra o grande esforço de Balzac em busca de entendimento do sentimento religioso, fato que, segundo ele, ajuda a compreender a obra do autor francês como uma tentativa de responder ao programa definido por ele próprio, Balzac, no prefácio do Livre Mystique: "qual forma assumirá o sentimento religioso, qual será a sua nova expressão", isto é, desenvolver um questionamento de uma ordem espiritual procurando torná-la "atraente como um romance moderno."17 (BIERCE, 2019, p. 805)

De mãos dadas com a subversão e a ironia, a dúvida e a fé, o sacro e o profano, com a realidade e a ficção, sendo desafiado, ao mesmo tempo, pelo entendimento do sentimento religioso e pela compreensão da humanidade, o criador de A Comédia Humana teria se inspirado no modelo da narrativa bíblica e na sua própria ideia do "retorno de Eva" para desenvolver o método do intenso vai-e-vem dos seus personagens e, principalmente, todo o seu complexo sistema narrativo?

A Comédia Humana poderia ser analisada como uma versão balzaquiana para um Moderno e "Terceiro Testamento"? Estaríamos diante de um ousado e surpreendente projeto de uma primeira Bíblia Mundana? Uma versão aclimatada a seu Tempo, mais cômica que sagrada, em que o Humano e o Divino tornam-se comediantes e, ao mesmo tempo, sérios personagens de uma crítica política e social? O fato é que a coleção de livros escritos por um único autor (Honoré de Balzac) e seu registro da ascensão definitiva do capitalismo na França, ao contrário do Antigo e Novo Testamentos (que são obras coletivas), teria feito até o ateu Karl Marx eleger Balzac como seu escritor predileto, segundo escreveu Georg Lukács: "É verdade que o Marx da fase da maturidade sempre acalentou o propósito de expor num alentado ensaio suas ideias sobre Balzac, seu escritor preferido" (LUKÁCS, 1965, p.11). Mas este ficou, como tantos outros, no terreno das aspirações. Uma das qualidades que Marx destacava nessa possível Bíblia Mundana de Balzac era "o profundo paralelismo psíquico entre o "alto" e o "baixo", reconhecendo de maneira clara que as formas de expressão do mundo inferior tem grandes vantagens em relação aos estratos superiores" (Ibid., p.156). Marx via em Balzac - assim como em Shakespeare - a tendência artística realista que melhor correspondia à estética marxista.

Com base no número de releituras, o ensaísta Miguel Unamuno intitula o romance Dom Quixote de a "Bíblia espanhola" (UNAMUNO apud BLOOM, 2009, p.100). Considerando a lógica de Unamuno, pela infinidade de leitores e releitores de Balzac em todo o mundo $A$ Comédia Humana mereceria, pelo menos, o status de Bíblia francesa. Uma Bíblia que recomeça a contar a saga da humanidade a partir de meados do século XIX e que faz de Paris metáfora de um Paraíso Infernal, onde a mulher chegou primeiro que o homem e este foi criado a partir de pedaços dos desejos femininos, como reconhece Félix em O Lírio do Vale: "Não sabe, então, que sou obra sua?" (BALZAC, 1959, p.405). Paraíso de um Deus incerto chamado Acaso: “(...) o dedo de Deus, tão frequentemente denominado Acaso, substitui a justiça humana" (BALZAC, 1958, v. VI, p.11); divino Acaso ora confundido com a Toda Poderosa Sociedade, como descreve o narrador de La Peau de Chagrin:

A Alta Sociedade expulsa do seu seio os infelizes [...]. Ela abomina as dores e os infortúnios, teme seu contágio, nunca hesita entre esses e os vícios: o

\footnotetext{
${ }^{16}$ (...) permet ainsi de faire tenir ensemble les opposés, le religieux et le matérialisme, le doute et la foi, et donne naissance à une unité radicalement polyphonique qui institue le doute et la réversibilité comme principes poétiques.

${ }^{17}$ (...) quelle forme revêtira le sentiment religieux, quelle en sera l'expression nouvelle [...] attrayant comme un roman moderne.
} 
vício é um luxo! [...] como as jovens romanas do Circo, nunca perdoa o gladiador que cai; vive de ouro e zombaria. Morte aos fracos! (BALZAC, 2008, p.248)

Nesse romance-laboratório, Balzac faz ensaios e começa a desenhar o seu projeto filosófico, literário e, principalmente, humano e "tenta fundamentar as suas opiniões acerca da Sociedade Humana (tipo humano diferenciado pelo meio) mediante analogias biológicas" (AUERBACH, 2009, p.425), como o próprio Balzac explica no prefácio de A Comédia Humana: “(...) a sociedade se assemelha à natureza [...]. Existiram, pois, e existirão sempre, espécies sociais como há espécies zoológicas” (BALZAC, 1959, v. XV, p.11), esclarece o autor no prefácio de A Comédia Humana. E no início dessa experiência literária e sociológica, Balzac elabora o protagonista Raphael de Valentin, o Adão reinventado balzaquiano, o arquétipo do Homem de Balzac - meio dândi, meio arrivista -, criado pelo autor para moldar seus futuros heróis como Eugène de Rastignac, Lucien de Rubempré, Charles Grandet, Félix Vandenesse, entre outros. Um Adão surpreendido por uma Eva que não nasceu dele e, muito pior do que isso, é fruto da diabólica imaginação de Balzac: a bela, rica, perversa e impiedosa cortesã Fedora que se tornou condessa: "O enigma oculto naquele rosto de mulher renascia. Fedora podia ser explicada de tantas maneiras que se tornara inexplicável" (BALZAC, 1959, v. XV, p.134).

A Bíblia Mundana de Balzac, então, começa com um casal formado por uma ex-cortesã e um dândi suicida perdidos no inferno parisiense: "Nossa consciência é um juiz infalível, quando ainda não a matamos" (Ibid., p.124). Na epígrafe do primeiro capítulo de La Peau de Chagrin, Balzac usa o desenho de uma serpente que aparece no romance Tristam Shandy, de Laurence Sterne, o que remete o leitor à figura subversiva da cobra do Jardim do Éden. A partir desse ponto, as conexões entre La Peau de Chagrin e a Bíblia se multiplicam ao longo da história balzaquiana. Assim como a narrativa bíblica, o romance também convoca o leitor a buscar um sentido filosófico para existência. O livro conta o drama de Raphael de Valentin, um jovem rico parisiense que, depois de ter fracassado na vida e no amor, decide se suicidar no rio Sena. Mas, antes de causar a própria morte, ele conhece o dono de um antiquário que lhe dá de presente a misteriosa pele de Onagro.

Onagro é o nome dado a uma espécie de jumento típico do deserto do Oriente Médio, cenário principal do Velho Testamento. Monsieur Lavrille, naturalista consultado por Raphael no romance de Balzac, ajuda a estabelecer o diálogo entre o asno e a narrativa bíblica: "(...) este animal foi tido durante muito tempo como fantástico. Como sabe ele é célebre na Escritura Sagrada. Moisés proibiu cruzá-lo com os congêneres. Mas o Onagro é ainda mais famoso pelos abusos de que foi objeto, e dos quais falam com frequência os profetas bíblicos" (BALZAC, 2008, p.220).

Segundo o personagem que presenteia Raphael, a pele do jumento é um talismã que vai ajudá-lo a realizar todos os desejos. E, de fato, com ajuda da pele mágica Raphael torna-se um homem poderoso, rico e cortejado pelos homens e mulheres mais influentes da França. E, vestido com a ironia balzaquiana, o protagonista debocha da Bíblia e de um dos mais importantes reis de Israel:

- Está vendo essa pele? É o testamento de Salomão. Salomão esse reizinho pretensioso, está em meu poder. Possuo a Arábia, mesmo a mais desértica. O Universo me pertence, você me pertence se eu quiser. (BALZAC, 2008, p.181) 
Em La Peau de Chagrin, a pele poderosa do jumento oriental, que enriquece Raphael de Valentin e concretiza seus sonhos, também remete o leitor conhecedor da Bíblia à pele que realiza o grande desejo de Jacó - e o transforma no patriarca fundador de Israel. Para roubar o direito à primogenitura do irmão mais velho Esaú, que era mais peludo do que ele, Jacó, orientado pela mãe Rebeca, cobre as mãos e o pescoço com peles de cabritos e assim se passa pelo irmão, conseguindo enganar o pai, Isaac, cego e à beira da morte: “(...) E tomou Rebeca as roupas de Esaú, seu filho maior, as limpas, que ela tinha em casa e vestiu Jacó, seu filho menor. E fez vestir as peles dos cabritos sobre suas mãos e a lisura de seu pescoço" (Gn 27,1516).

Ao segurar nas mãos de Jacó - e sentir os pelos dos cabritos - Isaac acredita estar diante do filho mais velho (que naquele momento estava caçando) e consagra o caçula traiçoeiro como o seu herdeiro político. Esaú fica sabendo que teve a benção roubada pela boca do próprio pai e se revolta contra o irmão que já tinha fugido; Esaú, então, promete a si mesmo que mataria Jacó.

A partir daí, Jacó começa a enfrentar o medo da vingança fraternal e, como Raphael de Valentin, passa a conviver com o fantasma da morte. No romance balzaquiano, o protagonista faz um pacto com a pele: a cada pedido atendido, o couro vai diminuindo de tamanho assim como a vida de Raphael. Desesperado com o poder da pele, o personagem de Balzac tenta entender a força daquela peça mágica, levando-a para ser analisada pelos melhores cientistas de Paris. Mas nem mesmo a ciência consegue decifrar e frear os poderes implacáveis da pele do jumento bíblico: "- Estou perdido! - exclamou Raphael - Deus está aí. Vou morrer." (BALZAC, 2008, p.232).

Ao contrário do que ocorre na obra de Balzac, o narrador bíblico não deixa claro se Jacó se desfaz das peles usadas na trapaça contra o irmão ou se as carrega com ele. Mas, durante a fuga, o filho de Rebeca segue atormentado pela cena da traição e, tomado pela culpa, tem vários sonhos com Deus e até luta contra ele. No entanto, ao invés de puni-lo, Deus lhe oferece uma escada para subir ao seu Reino, troca o seu nome para Israel e renova o juramento da Terra Prometida já feito aos outros patriarcas Abraão e Isaac.

O sonho de Jacó, ironizado pela pluma de Balzac, reaparece quase no final do romance, refletido no devaneio de Raphael. O narrador atribui ao poder do ópio as viagens da imaginação do protagonista que, nessa passagem da história, depois de uma noite de orgia, dormia como um anjo e, segundo o narrador, parecia ter a vida longa dos profetas e dos patriarcas da Torah: "Ele sorria certamente transportado em sonho a uma vida bela. Talvez tivesse cem anos, talvez os netos estivessem lhe desejando longos dias; talvez, sentado sob a folhagem em seu banco rústico sob o sol, avistasse, como o profeta, do alto da montanha, a terra prometida, numa distância benfazeja!” (BALZAC, 2008, p.273)

Essa imagem do protagonista balzaquiano comparada à de um patriarca bíblico já velho e centenário, cercado pelos descendentes, sentado num banco rústico, avistando do alto da montanha a Terra Prometida, está carregada de simbologia. Assim como os patriarcas Abraão, Isaac e Jacó, Raphael de Valentin, por ter sido o primeiro personagem de grande sucesso de Balzac, também não deixa de ter o papel de fundador ou de patriarca da Comédia Humana, que, por sua vez, seria a terra prometida de Balzac, ou seja, o seu ideal literário. Ao contar que Raphael sonhava como um profeta com a terra prometida, podemos supor que o narrador já estaria profetizando aos leitores os planos de Balzac para a realização de A Comédia Humana. Numa das cartas que escreve para Madame Hanska o próprio Balzac se compara ao principal patriarca do Judaísmo: "Acho-me agora exausto como Jacó após haver lutado com o anjo" (BALZAC apud ZWEIG, 1953, p.363). E em outra carta à amada proclama: "Sou o Judeu Errante do pensamento" (BALZAC apud RÓNAI, 1959, v. I, p. LX) 
Para a crítica Anne-Marie Baron, a Bíblia foi a maior influência literária de Balzac: "Ele vê nos personagens bíblicos, o modelo de verdades atemporais e de paradigmas humanos. [...] Esta é sem dúvida a chave para a abundante colheita de imagens bíblicas que voltam regularmente em A Comédia Humana [...]. A Bíblia parece ser seu modelo"18 (2018, p.13-14).

Para confirmar a sua tese, Anne-Marie Baron compara vários romances, contos e novelas, que compõem A Comédia Humana, com livros da Bíblia. Ela defende que eles praticam um surpreendente jogo intertextual. É o caso dos paralelos que ela traça e analisa entre o romance Ilusions perdues e o livro Eclesiastes; Le Lys dans la vallée com Cântico dos Cânticos - "era impossível não escutar a voz daquele eterno Cântico dos Cânticos pelo qual a natureza convida as criaturas ao amor" (BALZAC, 1959, v. XIV, p.270) - e Apocalipse e Coronel Chabert com o Livro de Jó, para citar alguns. Em Coronel Chabert, Baron chama a nossa atenção para a frase que o protagonista balzaquiano diz quando sai do buraco onde estava praticamente enterrado vivo: "saí da cova tão nu como saí do ventre da minha mãe" (BALZAC, 2012, p.347); segundo Baron, "trata-se da mesma expressão usada por Jó quando ele entende a razão das catástrofes sucessivas que se abatem sobre ele" (2018, p. 116).

O Livro de Jó também é citado por Balzac no romance Ilusões Perdidas, primeiramente para descrever o sofrimento a que foi submetido o seu protagonista, Lucien de Rubempré, a partir do momento em que ele passou a conviver com o submundo da imprensa parisiense. $\mathrm{O}$ colega Lousteau adianta as regras do jogo sujo que Lucien terá que entrar se quiser vencer na carreira de jornalista: "Ninguém ousa dizer o que lhe grito com a dor do homem atingido no coração e como um outro Jó sobre a esterqueira: eis aqui as minhas úlceras!" (BALZAC, 2013, p.307). Em outra parte do mesmo romance, a atriz e cortesã Florina, ao ser apresentada a Lucien pergunta: "É rico para se dedicar à poesia?" E Lucien responde: "Pobre como Jó" (Ibid., p.347).

Pesquisadores como Jean-Hervé Donnard e Saori Osuga também investigaram a influência da Bíblia na Comédia Humana. Donnard estudou as três maneiras principais de leitura da Bíblia realizadas por Balzac: a poética, a mística e a crítica. Osuga publicou vários artigos sobre o tema e escreveu o livro Séraphîta et la Bible, uma análise literária do romance balzaquiano chamado Séraphîta sobre uma bela e celestial história, ambientada na Escandinávia. O nome de Séraphîta é emprestado de um anjo do amor, um membro da mais alta ordem angélica. Um dos capítulos traz à luz uma série de monólogos de um padre sobre o misticismo pregado pelo teólogo sueco Emanuel Swedenborg. A profundidade dos pensamentos de Balzac e Swedenborg motivou os estudos de Osuga sobre a relação de Séraphîta com a Bíblia. Citando Jean-Hervé Donnard, Osuga esclarece:

O desejo que Balzac tinha de recorrer às fontes o incitou, desde a juventude, a pesquisar as melhores traduções da Santa Escritura. Nós conhecemos a existência de uma carta do jovem Balzac, que prova, como atesta Jean-Hervé Donnard, seu "louvável esforço de informação" neste assunto. Aos vinte anos, Balzac escreveu a Theodore Dablin (1783-1861), velho amigo da família dele e que o autor francês chamava, carinhosamente, de "meu querido pequeno pai”:

Eu gostaria de uma Bíblia bem completa, em latim e francês, se for possível. Eu não quero o Novo Testamento. Este eu já li. Eu creio que algo assim foi impresso recentemente na Desoër ou na Didot. Se a tradução francesa for difícil de encontrar ou se for muito cara, eu me ateria só à versão em latim. Eu não quero uma edição só na língua francesa. (DONNARD apud OSUGA, 2012, p.33)

\footnotetext{
${ }^{18}$ Il voit dans les personnages bibliques les parangons de vérités intemporelles et dans les situations de la Bible des paradigmes humains. [...] Telle est sans doute la clef de l'abondante moisson d'images bibliques qui reviennent régulièrement dans la Comédie Humaine. [...] La Bible semble bien être en cela son modèle.
} 
Segundo Osuga, "esta carta nos permite constatar que, naquela época, Balzac já tinha nas mãos uma edição do Novo Testamento em latim e em francês, e que ele desejava o Antigo Testamento em latim e francês" (OSUGA, 2012, p.33-34).

Não só desejava como tinha uma predileção especial pela narrativa primeva, também chamada de Bíblia Hebraica. O livro Eclesiastes, por exemplo, considerado, ao lado do Livro de $J o ́$, as duas joias raras da narrativa bíblica por Harold Bloom ${ }^{19}$ também teria chamado a atenção de Balzac como esclarecem as pesquisas de Roger Pierrot, no artigo "Balzac et L'Ecclésiaste":

Algumas citações do Eclesiastes figuram na obra balzaquiana. Duas delas implicam numa leitura mais atenta da Bíblia. E, sem dúvida, são, provavelmente, uma reminiscência que a liturgia católica passou para a cultura geral dos predecessores e contemporâneos de Balzac. (PIERROT, 1995, p.226)

E assim as histórias e os personagens bíblicos são citados, reinterpretados e até reinventados por Balzac. Apenas nos romances Ilusões Perdidas, Esplendores e Misérias das Cortesãs, Gobseck e Uma filha de Eva, obras em que a presença das figuras do demi-monde é intensa, os livros da Bíblia são lembrados 113 vezes. Seja numa citação direta, na reprodução de um nome, de uma cena, numa metáfora ou numa vaga menção, a narrativa e as figuras do Velho e Novo Testamentos trocam o deserto do Oriente pela glamorosa e decadente Paris oitocentista.

Em Le Père Goriot, romance que conta a saga de um pai que se sacrifica até à morte pelas duas filhas, o velho Goriot é comparado a Jesus Cristo por Balzac "Para bem descrever a fisionomia desse Cristo da paternidade, seria preciso ir buscar comparações nas imagens que os príncipes da paleta criaram para representar a paixão sofrida em benefício do mundo pelo Salvador dos homens" (BALZAC, 2012, p.250). Baron também destaca essa alegoria cristã presente no romance balzaquiano - "seu Cristo como Goriot" (BARON, 2018, p.48). Ele faz de tudo para evitar que as herdeiras se afoguem no lamaçal moral que alaga a sociedade parisiense e, ao tentar separar o bem do mal, selecionando e cercando-se dos melhores entre as espécies sociais, temendo uma tragédia iminente, também nos remete a outro herói bíblico, Noé, especialmente quando o narrador compara Paris a um mundo afogado:

Paris é um verdadeiro oceano. Sondai-o, jamais conhecereis sua profundidade. Percorreio-o, descrevei-o: por maiores cuidados que empregardes em percorrê-lo, em descrevê-lo; por mais numerosos e interessados que sejam os exploradores desse mar, sempre haverá nele um lugar virgem, um antro desconhecido, flores, pérolas, monstros, qualquer coisa inaudita, esquecida pelos mergulhadores literários. A Casa Valquer é uma dessas curiosas monstruosidades. (BALZAC, 2012, p.38)

Na Bíblia mundana de Balzac, o demi-monde parisiense torna-se a terra prometida de ladrões, assassinos, mulheres imorais, dândis, suicidas, libertinos, banqueiros, juízes e jornalistas corruptos, homens avarentos, senhoras adúlteras, femmes galantes efemmes venales.

19 "Imprimirei maior ênfase a Jó e ao Eclesiastes, obras-primas literárias, sendo Jó uma categoria à parte." (BLOOM, 2000, p.23). 
E na Paris balzaquiana, a rainha bíblica, heroína do Livro de Esther,empresta o seu nome à cortesã Esther Van Gobseck, protagonista feminina do romance Esplendores e Misérias das Cortesãs. Além do mesmo nome, as duas personagens são judias e órfãs. Mas as conexões entre essas mulheres não param por aí. Antes de entrar para o Velho Testamento, a história da jovem hebreia Esther por muito tempo foi marginalizada como a vida das cortesãs. O nome de Deus não aparece nenhuma vez na narrativa, ao passo que o nome de um rei pagão é mencionado mais de 150 vezes. Não há alusão à oração nem a algum tipo de serviço espiritual, com exceção do jejum. O texto é recheado de festas coloridas, regadas a vinho, que remetem o leitor atento às celebrações profanas como o carnaval. Nas entrelinhas da narrativa é possível deduzir que Esther, algumas vezes, também fez sexo com o rei Assuero antes do casamento. Ato pagão que, segundo a Bíblia, contraria as regras e os desejos divinos.

$\mathrm{O}$ jogo da sedução feminina usado de forma calculada e estratégica para conspirar e conquistar poder também conecta a história da Esther bíblica ao demi-monde francês. Esther esconde seu verdadeiro nome, Hadassá, e usa uma identidade falsa, um nome de guerra para ocultar sua real origem, uma prática muito comum às mulheres que mercantilizam o sexo: "Ele criara Hadassá - que era Esther - filha de seu tio, a qual não tinha nem pai nem mãe; e a moça era bela, de porte formoso e boa aparência" (Est 2,7).

Todos esses lampejos do mundo profano, tão presentes no espaço ocupado pelas cortesãs, por muitos séculos afastaram a história da rainha Esther do Cânone Sagrado. Martinho Lutero desejou que a narrativa da rainha do povo judeu não existisse em virtude daquilo que considerou como “indiscrições pagãs" (MCCLARTY, 1989, p.10).

Segundo a pesquisadora Wilma McClarty, da Universidade de Montana, "antigos estudiosos judeus questionavam se a leitura do Livro de Esther não seria capaz de contaminar as mãos!" (Ibid., p.10).

Nas reflexões que Balzac publicou em Fisiologia do Casamento ou Meditações de Filosofia Eclética acerca da felicidade e da infelicidade conjugal, o autor de A Comédia Humana sinaliza que, de fato, leu o Livro de Esther. Assim, Balzac escreve:

\begin{abstract}
A história ensina-nos que Assuero, querendo tomar por mulher uma das donzelas da Pérsia, escolhera Esther, a mais virtuosa e a mais bela. É, pois, claro, que os seus ministros tinham necessariamente encontrado um meio qualquer de vasculhar a população. Infelizmente, a Bíblia tão clara sobre todas as questões matrimoniais, esqueceu-se de nos transmitir esta lei de eleição conjugal. (BALZAC, 1959, v. XVII, p.252)
\end{abstract}

Essa preocupação de Balzac com os relacionamentos conjugais é um tema recorrente na Comédia Humana. No comentário acima sobre o Livro de Esther, Balzac parece ter dúvidas a respeito da legalidade do casamento entre Assuero e a bela judia. Podemos até pensar que ele acreditava que Assuero tinha que ter lutado mais para manter-se bem casado com ainha Vahsti e não ter sucumbido aos encantos da sedutora Esther. Ao afirmar que a Bíblia "esqueceu-se de nos transmitir esta lei de eleição conjugal", Balzac dá sinais de que refletiu e tentou encontrar explicações nas entrelinhas do relato bíblico para a meteórica ascensão da jovem escrava hebreia ao posto de rainha da Pérsia. Segundo o narrador de Esplendores e Misérias das Cortesãs, Balzac acreditava que a rainha judia, como as cortesãs, vendeu o seu corpo para se tornar uma mulher poderosa. Nesta passagem do romance balzaquiano podemos conferir como a narrativa subjetivamente remete o leitor às duas Esther: "As cortesãs zombam das leis, elas adoram uma certa delicadeza; sabem vender-se como Esther, por um belo ideal secreto, que é a sua religião" (BALZAC, 2015, p.274). 
O romance Esplendores e Misérias das Cortesãs inicia-se com um baile de máscaras na Ópera de Paris. A prostituta Esther Van Gobseck, mais conhecida no demi-monde parisiense como Torpedo - "aquela rapariga era tão atraente que seria capaz de entorpecer o próprio Napoleão" (Ibid., p.49) -, faz de tudo para não ser reconhecida porque está acompanhada do seu grande amor, Lucien de Rubempré. E, para tanto, como todos que estão nos salões do suntuoso teatro, Esther também está misteriosamente mascarada. Mesmo assim, alguns amigos de Lucien reconhecem, na acompanhante do poeta, a famosa cortesã. Eis um fato praticamente fundador dessa nova trama que marca o retorno de Lucien de Rubempré para tentar a sorte pela segunda vez em Paris. $\mathrm{O}$ fracassado passado do jovem arrivista na capital francesa é narrado no romance Ilusões Perdidas.

O Livro de Esther também começa com uma festa profana. Assuero, o rei da Pérsia, oferece um grande banquete para todos os seus ministros das províncias e a grande maioria dos seus servos para comemorar as conquistas do seu império e o seu valor enquanto líder político. Mas, ao contrário da cortesã balzaquiana, a Esther bíblica não será desmascarada ou tampouco chantageada. Ela mesma revelará sua verdadeira origem ao rei: "Porque fomos vendidos, eu e meu povo, para nos destruírem, matarem e aniquilarem de vez!" (Est 7,4).

Ao colocar lado a lado as duas Esther, Anne-Marie Baron conclui: a "Esther balzaquiana se parece muito com a bela jovem judia da diáspora persa que deixou o harém para tornar-se rainha" ${ }^{20}$ (BARON, 2018, p.100). No entanto, a pesquisadora destaca uma diferença gritante que impera entre as duas personagens: enquanto a cortesã perdidamente apaixonada por Lucien prefere o suicídio à vida dupla e fingida, a rainha persa revela-se dona de uma força soberana diante do jogo político que a desafia, mas que "faz de Deus sua única felicidade" 21 (Ibid.).

O livro de Esther, O livro de Gênesis, a saga dos Patriarcas, o livro de Jó, o Cântico dos Cânticos, o Apocalipse, Eclesiastes, toda essa florada de referências bíblicas vive uma eterna primavera na obra de Balzac e, no labirinto da influência, o suposto sonho balzaquiano de escrever uma Bíblia Mundana pode estar perdido. Talvez se trate mesmo de um sonho que o próprio Balzac sugeriu muito sutilmente aos leitores no prefacio que escreveu para sua extensa obra. Assim, diz o romancista: "A ideia inicial da Comédia Humana surgiu como um sonho, como um desses projetos impossíveis que acariciamos e que deixamos voar; uma quimera que sorri, que mostra seu rosto de mulher e que tão logo estende suas asas subindo em um céu fantástico" (BALZAC, 1959, v. I, p.19).

Mas, como muitos críticos já pontuaram, o valor documentário da obra de Balzac jamais pode ser esquecido. São livros onde historiadores e sociólogos colhem dados sobre os fenômenos mais diversos da primeira metade do século XIX. Em relação aos atos revolucionários de julho de 1830, por exemplo, em que o povo, liderado pela burguesia liberal, derrubou Carlos X e colocou um ponto final no período conhecido como a Restauração Francesa, esclarece Dolf Oehler: "falta disposição para encarar os fatos de frente. Dentre os escritores da época de julho só o ultraconservador Balzac a possui. Ele é o único em cuja obra penetra a materialidade da nova França com toda a sua riqueza épica" (OEHLER, 1997, p.31). Mesmo considerado completamente conservador por alguns críticos, segundo Paulo Rónai,

Balzac pode ser citado como um "oráculo" pela extrema direita e pela extrema esquerda. As correntes políticas mais antagônicas servem-se do nome do romancista como de um escudo: Léon Daudet explora-o em seus ataques ao estúpido século XIX, ao passo que Marx e Engels o consideram uma das

\footnotetext{
20 (...) l'Esther balzacienne ressemble beaucoup à la jolie petite juive de la diaspora persane, sortie du harem pour devenir reine.

${ }^{21}$ (...) mais qui fait de YHVH son seul bonheur.
} 
principais testemunhas de acusação no grande processo do capitalismo e da burguesia. (RÓNAI, 2012, p.15)

Em contrapartida, esse papel de oráculo ideológico, desempenhado por Balzac e por outros escritores, é duramente criticado por Roland Barthes:

\begin{abstract}
A ideologia passa sobre o texto e sua leitura como o rubor sobre um rosto (em amor, alguns apreciam eroticamente esse vermelho); todo escritor de prazer tem suas ruborizações imbecis (Balzac, Zola, Flaubert, Proust; somente Mallarmé talvez é senhor de sua pele): no texto de prazer, as forças contrárias não se encontram mais em estado de recalcamento, mas de devir: nada é verdadeiramente antagonista, tudo é plural. (BARTHES, 1987, p.42-43)
\end{abstract}

De faces múltiplas e frequentemente contraditórias, como a própria sociedade, A Comédia Humana presta-se a todas as interpretações. Incluindo aqui a que ganhou força nos últimos anos, defendida por Anne-Marie Baron, André Vanoncini, Max Andréoli, entre outros pesquisadores, que, diante do perturbador e irônico sentimento religioso de Balzac e da sua suposta e desconcertante Bíblia Mundana, consideram o escritor, proclamado pela crítica como o pai do Realismo, bem mais merecedor do rótulo de autor-filósofo do que o de autor-realista.

\title{
Referências Bibliográficas
}

\section{Obras de Honoré de Balzac}

BALZAC, Honoré de. A pele de Onagro. In: . A Comédia Humana. Vol. XV. Porto Alegre: Globo, 1959. . A pele de Onagro. São Paulo: L\&PM, 2008. . Coronel Chabert. In: A Comédia Humana. Vol. IV. Porto Alegre: Globo, 1958. Esplendores e Misérias das Cortesãs. In: . A Comédia Humana. Vol. IX. São Paulo: Globo, 2015. . Illusions Perdues. Paris: Le Livre de Poche, 2008.

Globo, 2013. Ilusões Perdidas. In: . A Comédia Humana. Vol. VII. São Paulo: Fisiologia do Casamento. In: . A Comédia Humana. Vol. XVII. Porto Alegre: Globo, 1959.

Globo, 1959. Gobseck. In: A Comédia Humana. Vol. III. Porto Alegre: Le père Goriot. Paris: Gallimard, 1971. Louis Lambert. In: A Comédia Humana. Vol. XVII. Porto Alegre: Globo, 1959.

O Lírio do Vale. In: . A Comédia Humana. Vol. XIV. Porto Alegre: Globo, 1959.

Globo, 2012. O pai Goriot. In: A Comédia Humana. Vol. IV. São Paulo: Séraphita. In: . A Comédia Humana. Vol. XVII. Porto Alegre:

Globo, 1959. Splendeurs et misères des courtisanes. Paris: Le Livre de Poche, 2008. 
Porto Alegre: Globo, 1958.

Uma Filha de Eva. In:

A Comédia Humana. Vol. II. Porto

Alegre: Globo, 1958.

\section{Edições da Bíblia}

La Bible. Traduction de Lemaître de Sacy. Paris: Robert Laffont, 1990.

A Bíblia de Jerusalém. Tradução do texto em língua portuguesa diretamente dos originais. (Introdução e notas de La Bible de Jérusalem, 1998, publicada sob a direção da École Biblique de Jerusalém, edição em língua francesa, Paris: Les Éditions du Cert, 1998). Edição revista pela Sociedade Bíblica Católica Internacional, São Paulo: Paulus, 2002.

Bíblia Hebraica. Tradução de David Gorodovits e Jairo Fridlin. São Paulo: Sêfer, 2006.

\section{Outras Referências}

ALTER, Robert. A Arte da Narrativa Bíblica. São Paulo: Companhia das Letras, 2007. ; Sasson, Jack M. (Orgs.). Guia Literário da Bíblia. Tradução de Raul Fiker. São Paulo: Editora UNESP, 1997. Strong as Death is Love. New York: W.W. Norton \& Company, 2015.

ARISTÓTELES. Poética. São Paulo: Editora 34, 2019.

AUERBACH, Erich. Mimesis. São Paulo: Perspectiva, 2009.

BARON, Anne- Marie. Balzac et la Bible. Paris: Honoré Champion Éditeur, 2018.

BARTHES, Roland. O Prazer do Texto. São Paulo: Perspectiva, 1987.

BERTAULT, Philippe. Balzac et la Religion. Genève: Slatkine Reprints, 2002.

BERTHIER, Philippe. Du côté de Sodome. In: LECHEVALIER, Agathe Novak. Essai, dossier et commentaires à propos de Splendeurs et Misères des Courtisanes, Paris: Gallimard, 2010, p.223-226.

BIERCE, Vincent. Le Sentiment religieux dans La Comédie Humaine - Foi, ironie et ironisation. Paris: Classiques Garnier, 2019.

BLOOM, Harold. Onde encontrar a sabedoria. Rio de Janeiro: Objetiva, 2009. A Anatomia da influência. Rio de Janeiro: Objetiva, 2013.

DONNARD, Jean-Hèrve. Balzac, lecteur de la Bible. In: L'année Balzacienne, Paris, 1988, p.7-26.

FRYE, Northrop. Código dos Códigos - A Bíblia e a Literatura. São Paulo: Boitempo, 2006. L'ANNÉE BALZACIENNE. Paris: Presses Universitaires de France, Edições 1960-2019.

LECHEVALIER, Agathe Novak. Essai, dossier et commentaires à propos de Splendeurs et Misères des Courtisanes. Paris: Gallimard, 2010.

LUKÁCS, Georg. Introdução aos Escritos Estéticos de Marx e Engels. In: Ensaios sobre Literatura. Rio de Janeiro: Civilização Brasileira, 1965, p.11-42.

MCCLARTY, Wilma. O livro de Ester como literatura? Nova abordagem a uma história antiga. In: Revista Diálogo, 2, 1989. Disponível em: <https://pt.scribd.com/document/227037771/012-mcclarty-p>. Acesso em: 12 jan. 2018.

OEHLER, Dolf. Quadros Parisienses - Estética antiburguesa em Baudelaire, Daumier e Heine (1830-1848). Sao Paulo: Companhia das Letras, 1997.

OSUGA, Saori. Séraphita et la Bible. Paris: Honoré Champion Éditeur, 2012.

PARIZET, Sylvie. La Bible dans les Littératures du Monde. Paris: Les Éditions du Cerf, 2016. PIERROT, Roger. Balzac et L'Ecclésiaste. Jerusalém: Universidade Hébraïque, 1995.

RÓNAI, Paulo. O Mundo de Balzac. In: Balzac e A Comédia Humana. São Paulo: Globo, 2012, p. XV-LXXVII.

. Advertência ao leitor. In: A Comédia Humana. Vol. I. Porto Alegre: Globo, 1959. 
. A vida de Balzac. In: A Comédia Humana. Vol. I. Porto Alegre: Globo, 1959. SCHAFFNER, Alain. Honoré de Balzac - La Peau de Chagrin. Études Littéraires. Paris: PUF - Presses Universitaires de France, 1996.

SELLIER, Philippe. Préface. In: La Bible. Paris: Robert Lafond, 1990, p. XI-LIII. ZWEIG, Stephan. Balzac. In: Obras Completas. Tomo XIX. Rio de Janeiro: Delta, 1953, p.6426. 